\title{
Clinical Significance of ErbB Receptor Family in Urothelial Carcinoma of the Bladder: A Systematic Review and Meta-Analysis
}

\author{
Yuh-Shyan Tsai, ${ }^{1}$ Hong-Lin Cheng, ${ }^{1}$ Tzong-Shin Tzai, ${ }^{1,2}$ and Nan-Haw Chow ${ }^{3}$ \\ ${ }^{1}$ Department of Urology, National Cheng Kung University Hospital, Tainan 70403, Taiwan \\ ${ }^{2}$ Department of Urology, College of Medicine, National Cheng Kung University, Tainan 70403, Taiwan \\ ${ }^{3}$ Department of Pathology, College of Medicine, National Cheng Kung University Hospital, Tainan 70403, Taiwan
}

Correspondence should be addressed to Tzong-Shin Tzai, tts777@mail.ncku.edu.tw and

Nan-Haw Chow, chownh@mail.ncku.edu.tw

Received 4 April 2012; Revised 16 May 2012; Accepted 16 May 2012

Academic Editor: Trinity J. Bivalacqua

Copyright (C) 2012 Yuh-Shyan Tsai et al. This is an open access article distributed under the Creative Commons Attribution License, which permits unrestricted use, distribution, and reproduction in any medium, provided the original work is properly cited.

The prognostic importance of examining ErbB receptor family expression in human bladder cancer remains uncertain. Using published evidence, we examined the clinical value and the updated results of clinical trials targeting ErbB receptor family members. Twenty-seven articles from 65 references related to ErbB receptor expression assessment in bladder cancer were reviewed. The estimates included the association significance, hazard ratios, and 95\% confidence intervals (CIs) from actuarial curves and survival analyses. A meta-analysis was done on those reports using univariate log-rank tests or a Cox-regression model. The methods of analysis and study subjects chosen varied widely among studies. The overall risks of disease progression for patients with EGFR or ErbB2 overexpression were 4.5 (95\% CI: 2.5-8.4) and 1.1 (95\% CI: 0.6-1.9), and the risks of mortality were 3.0 (95\% CI: 1.6-5.9) and 1.1 (95\% CI: 1.0-1.2), respectively. However, the significance of coexpression patterns of the ErbB receptor family remains controversial. None of six clinical trials yielded convincing results for blockading ErbB receptor signaling in urothelial carcinoma. The results of this analysis suggest that assessing co-expression patterns of the ErbB family may provide better prognostic information for bladder cancer patients.

\section{Introduction}

One characteristic of bladder cancer is its variable patient prognosis. About $70 \%$ of superficial (Ta and $\mathrm{T} 1$ ) tumors recur, and $10-20 \%$ of them become invasive [1]. Tumors that are invasive at primary diagnosis carry a high risk of progression despite radical cystectomy and other auxiliary treatments. Conventional prognostic factors, such as tumor stage, grade, size, and multifocality, do not accurately predict the clinical outcome for some patients. Therefore, extensive efforts have been made to identify biomarkers for predicting disease progression, response to treatment, and chance of long-term survival. Currently, it is recommended that patients with bladder cancer have regular urinary cytology, cystoscopy, and imaging studies at followup [2].
The ErbB receptor family (also known as the epidermal growth factor receptor (EGFR) family) is a major class of receptor tyrosine kinase (RTK) protooncogenes. They are important in many cell regulatory processes, such as proliferation, migration, adhesion, and, potentially, cellular transformation, including urothelial carcinogenesis. The ErbB family consists of 4 members: ErbB1 (also called EGFR and HER1), ErbB2 (c-erbB-2 and HER2/neu), ErbB3 (HER3), and ErbB4 (HER4). Dimerization by binding two monomers is the regulatory mechanism for activating RTKs [3]. In some cases, the formation of heterodimeric complexes allows interaction and crosstalk between different receptors of the same subfamily, and the ErbB receptor family is the best example of homo- and heterodimerization in vivo $[4,5]$. Therefore, clarifying the clinical significance of ErbB 
expression may provide important molecular targets for cancer therapy.

EGFR signaling regulates biological processes important for the pathogenesis of human cancers, including lung cancer, breast cancer, and prostate cancer [6]. In practice, therapy that targets EGFR gene mutations in primary tumors has extended the theme of targeted cancer therapies [7]. In breast cancer, HER2 amplification status is a pivotal biomarker in predicting response to chemotherapy [8], and a humanized anti-HER2 monoclonal antibody (trastuzumab) improved the survival of HER2-positive breast cancer patients [9]. The prognostic significance of ErbB receptor signaling has tissuespecific relevance. For example, EGFR/HER2-MAPK axis is important in human breast cancer while the kinase activity of the HER2/ErbB3 axis plays a major role in the DNA binding and androgen receptor stability in prostate cancer [10]. Moreover, the EGFR inhibitor gefitinib is ineffective in treating hormone-refractory prostate cancer, a result questioning the significance of the EGFR/HER2 axis in the molecular pathogenesis of prostate cancer [11].

To establish the clinical relevance of ErbB receptor family members in bladder cancer, we systematically reviewed the papers published in the past two decades on ErbB receptor family expression, either one of the members or the coexpression patterns, and their impact on patient prognosis. Our objectives were to confirm the significance of ErbB receptor expression in predicting recurrence, progression, and mortality in patients with bladder cancer, to identify factors that might affect the prognostic evaluation of ErbB receptors, and to conduct a meta-analysis of available estimates. In addition, we assessed the potential sources of heterogeneity underlying the conflicting results, and incorporated quantitative methods to analyze the data. The updated results of clinical trials targeting ErbB receptor signaling were also reviewed.

\section{Materials and Methods}

2.1. Search Strategy and Selection Criteria. Original articles published between January 1985 and May 2011 showing prognostic significance of expression or amplification of ErbB receptor members in patients with bladder cancer were systematically reviewed. Using the keywords "EGF", "EGFR," "c-erb-B1," "c-erb-B2," "c-erb-B3," "c-erb-B4," "neu," "epidermal growth factor," and "bladder neoplasms or transitional cell carcinomas-in-humans," we identified 710 relevant articles in the PubMed database. The number of studies was reduced to 65 by limiting the search to "prognosis" or "survival," including disease recurrence and progression. Duplicate data, identified in the same cohort by reviewing the interstudy similarities of investigators, source of patients, recruitment period, or inclusion criteria, were excluded from the current analysis. Only the largest series were included in our analysis.

2.2. Data Extraction, Handling, and Analyses. Our database was designed to ensure the breadth of relevant data obtained, based on study design, patient outcomes, tumor characteristics, statistical analyses, biological samples, analytical methods (namely, immunohistochemistry [IHC], fluorescence in situ hybridization [FISH], and real-time polymerase chain reaction $[\mathrm{RT}-\mathrm{PCR}]$ ), and the incidence of overexpression or gene amplification of ErbB receptor family members.

Two methods were used to summarize the results. Because most articles provided only the $P$ values or statements of whether results were significant (and no other measures of effect), the analyses of recurrence, progression, mortality, progression-free survival, disease-free survival, and resistance to chemotherapy and radiotherapy were based on definitions in the original reports. Briefly, recurrence was defined as a tumor that reappeared in the urinary bladder not at a higher $\mathrm{T}$ stage, while disease progression was defined as any tumor with a higher $\mathrm{T}$ stage in the local tumor, node, or metastasis. The $P$ values (or statements of significance) were extracted from association analyses $\left(\chi^{2}\right.$ test, Fisher's exact test, Student's $t$-test, the Mann-Whitney $U$-test, and logistic regression), and the risk estimates and 95\% confidence intervals (CIs) from univariate (Kaplan-Meier curves and the log-rank test) and multivariate survival (Cox regression) analyses. Data are summarized by providing the means of percentages or actual numbers with either the standard deviation (SD) or range. $\chi^{2}$ tests and Fisher's exact tests were used, when appropriate, to assess the independence of two categorical variables. Unconditional logistic regression models were used to identify the significance of study characteristics $(P<0.05)$.

A meta-analysis using multivariate tests was then done. Wolf's method was used to combine the risk estimates by applying the inverse of variance as the weighting factor. Potential sources of heterogeneity were investigated using graphical methods, such as the Galbraith plot. A heterogeneity test based on the statistics was done in all metaanalyses. The heterogeneity was considered significant when $P<0.10$. In cases of substantial heterogeneity, randomeffect models were used. The extent to which the combined risk estimate was affected by individual study was examined by consecutively omitting every study from the metaanalysis. Metaregression was used to explain the potential heterogeneity from the same characteristics included in the $P$ value analysis. The publication bias was investigated using Egger's and Begg's graphical methods. The analyses were done using Comprehensive Meta Analysis Version 2 (Biostat, Englewood, NJ, USA). Significance was set at $P<0.05$ (two sided).

\section{Results}

3.1. Significance of Individual ErbB Receptor Expression. Tumors recurred in 1233 patients in 16 analyses reported in 8 studies (median: 162 patients; range: 52-243) (Table 1) $[5,12-18]$. The receptor members analyzed in order of frequency were ErbB2 (7 of 8) and EGFR (6 of 8). Three studies $[5,15,16]$ reported significantly positive results. After data processing, only 4 reports were accepted for analysis: 2 for EGFR and 2 for ErbB2 (Figure 1(a)). The distribution of the tumor stages in patients with cancer varied widely. All four studies used IHC to analyze their study samples. Overall, the hazard ratios of tumor recurrence were 1.588 (95\% CI: 0.9-2.7). 
TABLE 1: Significance of ErbB receptor family as a marker for tumor recurrence.

\begin{tabular}{|c|c|c|c|c|}
\hline Study name & Methods & Pts no. & Study subject & Significance \\
\hline \multicolumn{5}{|l|}{ EGFR } \\
\hline [12] & IHC & 230 & T0-1 & NS \\
\hline$[13]$ & IHC & 73 & T2-4 & NS \\
\hline$[14]$ & IHC & 141 & T0-1 & NS \\
\hline [15] & IHC & 52 & T0-1 & Yes \\
\hline [16] & IHC & 182 & T0-4 & Yes \\
\hline [5] & $\mathrm{IHC}$ & 245 & T0-4 & NS \\
\hline \multicolumn{5}{|l|}{ ErbB2 } \\
\hline$[16]$ & IHC & 182 & T0-4 & NS \\
\hline$[12]$ & IHC & 230 & T0-1 & NS \\
\hline [13] & IHC & 55 & T2-4 & NS \\
\hline$[14]$ & IHC & 141 & T0-1 & NS \\
\hline [17] & IHC & 62 & T0-1 & NS \\
\hline$[18]$ & IHC & 248 & T0-1 & NS \\
\hline$[5]$ & IHC & 245 & T0-4 & Yes \\
\hline \multicolumn{5}{|l|}{ ErB3 } \\
\hline$[16]$ & IHC & 128 & T0-4 & NS \\
\hline [5] & IHC & 245 & T0-4 & Yes \\
\hline \multicolumn{5}{|l|}{ ErbB4 } \\
\hline$[16]$ & IHC & 124 & T0-4 & NS \\
\hline
\end{tabular}

IHC: immunohistochemistry.

For cancer progression, 484 patients from 9 analyses were reported in 8 studies (median: 60 patients; range: 21-113) (Table 2) $[15,19-24]$. The receptor members analyzed in order of frequency were ErbB2 (5 of 8) and EGFR (4 of $8)$. Four studies $[15,19,20,22]$ found significantly positive results. After data processing, only 4 reports on EGFR and 3 on ErbB2 were accepted for analysis (Figure 1(b)). The distribution of tumor staging varied widely. All four studies used IHC to analyze their study samples. Overall, the hazard ratios of cancer progression were 4.611 (95\% CI: $2.5-$ 8.4) for EGFR and 1.067 (95\% CI: 0.59-1.97) and ErbB2 overexpression.

Cancer-related mortality in 3444 patients from 31 analyses was reported in 20 studies (median: 88 patients, range: 39-1500) (Table 3) $[5,13,15,16,19-27,34-37]$. The receptor members analyzed in order of frequency were ErbB2 (18 of 20) and EGFR 8 of 20). Thirteen studies [5, 13, 15, $16,21-23,26,34-37]$ reported significantly positive results. After data processing, only 3 reports on EGFR and 10 on ErbB2 were accepted for analysis (Figure 2). The distribution of tumor staging also varied widely. IHC was the most common method of assessment; however, FISH was used in 1 study, and gene copy amplification was used in another. Overall, the hazard ratios of cancer death were 3.044 (95\% CI: 1.6-5.9) for EGFR and 1.090 (95\% CI: 1.0-1.2) for ErbB2 overexpression.

3.2. Significance of the Coexpression Pattern of ErbB Receptors. Three studies $[5,16,28]$ investigated the significance of the coexpression patterns of ErbB receptor family members in association with tumor recurrence and patient survival.
None of the coexpression patterns were significant in predicting tumor recurrence. In contrast, several coexpression patterns were independent prognostic indicators of bladder cancer death, namely, EGFR-ErbB2, ErbB2-ErbB3 [5], and high EGFR or ErbB2 plus low ErbB3 or ErbB4 [16, 28] (Table 4).

3.3. Assessment and Publication Bias. A substantial funnel plot asymmetry suggestive of the publication bias was revealed for ErbB2 (Figure 3(b)). However, no obvious funnel plot asymmetry was found for EGFR, possibly because only 4 studies were analyzed (Figure 3(a)).

\subsection{Clinical Trials of Targeting ErbB Signaling in Human} Bladder Cancer. Until February 2012, there were 6 finished clinical trials targeting ErbB signaling in human bladder cancer (Table 5). Cetuximab is a chimeric (mouse/human) monoclonal antibody for blocking EGFR signaling. A phase II clinical trial [38] of 39 pretreated patients with metastatic urothelial carcinoma demonstrated that combined cetuximab and paclitaxel chemotherapy yielded a better response rate $(28.5 \%)$ than did cetuximab monotherapy, in which 9 of 11 patients had disease progression at 8 weeks.

Gefitinib is the first selective inhibitor of the EGFR tyrosine kinase domain. An overall response rate of $42.6 \%$ (95\% CI: $29.2-56.8 \%$ ) was demonstrated in a phase II trial of 58 patients with metastatic urothelial carcinoma treated with gemcitabine and cisplatin chemotherapy plus gefitinib $[39,40]$, the median survival time was 15.1 months (95\% CI: $11.1-21.7 \mathrm{mo}$ ), and time to progression was 7.4 months (95\% CI: $5.6-9.2 \mathrm{mo}$ ). Twenty-five patients completed the 


\begin{tabular}{|c|c|c|c|c|c|c|c|}
\hline Study name & & ubgroup within study & & Statist & ics for eac & h study & \\
\hline & & & $\begin{array}{c}\text { Hazard } \\
\text { ratio }\end{array}$ & $\begin{array}{c}\text { Lower } \\
\text { limit }\end{array}$ & $\begin{array}{l}\text { Upper } \\
\text { limit }\end{array}$ & $\begin{array}{r}Z \\
\text { valu }\end{array}$ & \\
\hline (Chakravarti et al., 2005) & & EGFR IHC (T2-4) & 0.420 & 0.103 & 1.708 & 1.2 & \\
\hline (Chakravarti et al., 2005) & & HER2 IHC (T2-4) & 1.080 & 0.459 & 2.543 & 0.17 & \\
\hline (Lipponen and Eskelinen, 1 & 994) & EGFR IHC (T0-1) & 4.148 & 1.506 & 11.42 & 2.75 & \\
\hline (Pich et al., 2002) & & HER2 IHC (T0-1) & 2.423 & 0.685 & 8.571 & 1.37 & \\
\hline & & & 1.588 & 0.928 & 2.715 & 1.68 & \\
\hline & & & (a) Bla & dder cance & $r$ recurren & & \\
\hline Study name & Subg & group within study & & Statistics & for each $\mathrm{s}$ & tudy & \\
\hline & & & $\begin{array}{c}\text { Hazard } \\
\text { ratio }\end{array}$ & $\begin{array}{l}\text { Lower } \\
\text { limit }\end{array}$ & $\begin{array}{l}\text { Upper } \\
\text { limit }\end{array}$ & $\begin{array}{c}Z \\
\text { value }\end{array}$ & $\begin{array}{c}P \\
\text { value }\end{array}$ \\
\hline (Ravery et al., 1995) & & FR IHC (T0-4) & 4.071 & 1.285 & 12.902 & 2.386 & 0.017 \\
\hline (Chakravarti et al., 2005) & & FR IHC (T2-4) & 0.140 & 0.019 & 1.034 & 1.928 & 0.054 \\
\hline (Neal et al., 1990) & & FR IHC (T0-1) & 29.60 & 4.848 & 180.7 & 3.670 & 0.000 \\
\hline (Popovet al., 2004) & EG & FR IHC (T0-4) & 6.058 & 2.651 & 13.840 & 4.273 & 0.000 \\
\hline & & & 4.611 & 2.529 & 8.406 & 4.988 & 0.000 \\
\hline
\end{tabular}

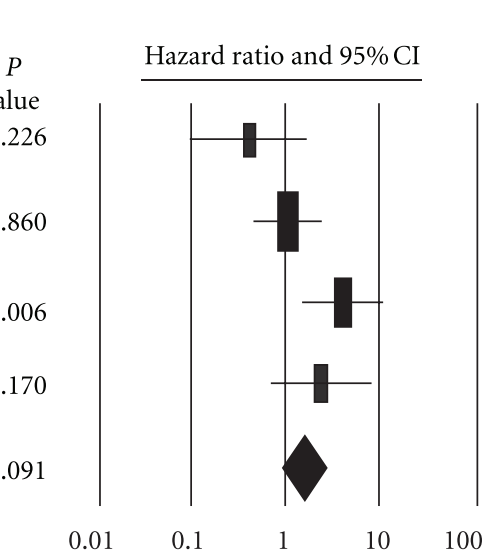


TABLE 2: Significance of ErbB receptor family as a marker for cancer progression.

\begin{tabular}{ccccc}
\hline Study name & Methods & Pts no. & Study subject & Significance \\
\hline EGFR & & & & \\
{$[19]$} & IHC & 57 & T0-4 & Yes \\
{$[13]$} & IHC & 73 & T2-4 & NS \\
{$[15]$} & IHC & 52 & T0-1 & Yes \\
{$[20]$} & IHC & 113 & T0-4 & NS \\
\hline ErbB2 & & 62 & T0-4 & NS \\
{$[21]$} & FISH & 55 & T2-4 & Yes \\
{$[13]$} & IHC & 39 & T3-4 & NS \\
{$[22]$} & IHC & 21 & T0-1 & T2-4 \\
{$[23]$} & IHC & 67 & & \\
{$[24]$} & IHC & & & \\
\hline
\end{tabular}

TABLE 3: Significance of ErbB receptor family as a marker for bladder cancer death.

\begin{tabular}{|c|c|c|c|c|}
\hline Study name & Methods & Pts no. & Study subject & Significance \\
\hline \multicolumn{5}{|l|}{ EGFR } \\
\hline [13] & IHC & 73 & $\mathrm{~T} 2-4$ & Yes \\
\hline$[25]$ & IHC & 109 & $\mathrm{~T} 2$ & NS \\
\hline$[16]$ & $\mathrm{IHC}$ & 182 & T0-4 & NS \\
\hline [26] & $\mathrm{IHC}$ & 59 & $\mathrm{~T} 2-4$ & Yes \\
\hline$[27]$ & IHC & 141 & $\mathrm{~T} 2-4$ & NS \\
\hline \multirow{2}{*}[15]{} & IHC & 52 & T0-1 & NS \\
\hline & IHC & 101 & T0-4 & Yes \\
\hline$[26]$ & RT-PCR & 59 & $\mathrm{~T} 2-4$ & Yes \\
\hline$[28]$ & RT-PCR & 88 & T0-4 & NS \\
\hline [29] & qRT-PCR & 73 & T0-4 & NS \\
\hline \multicolumn{5}{|l|}{ ErbB2 } \\
\hline [30] & Gene amplification & 163 & T0-4 & Yes \\
\hline$[31]$ & Gene amplification & 57 & T0-4 & Yes \\
\hline$[21]$ & FISH & 62 & T0-4 & NS \\
\hline$[32]$ & FISH & 1500 & T0-4 & NS \\
\hline [13] & IHC & 55 & $\mathrm{~T} 2-4$ & NS \\
\hline$[22]$ & IHC & 39 & T3-4 & Yes \\
\hline [25] & $\mathrm{IHC}$ & 109 & $\mathrm{~T} 2$ & NS \\
\hline [33] & IHC & 80 & $\mathrm{~T} 2-4$ & NS \\
\hline$[16]$ & IHC & 184 & T0-4 & NS \\
\hline$[34]$ & $\mathrm{IHC}$ & 90 & $\mathrm{~T} 2-4$ & Yes \\
\hline$[35]$ & IHC & 138 & $\mathrm{~T} 2-4$ & Yes \\
\hline$[36]$ & IHC & 132 & $\mathrm{~T} 2-4$ & Yes \\
\hline$[27]$ & IHC & 141 & $\mathrm{~T} 2-4$ & NS \\
\hline [37] & $\mathrm{IHC}$ & 88 & T0-4 & Yes \\
\hline$[32]$ & $\mathrm{IHC}$ & 1500 & T0-4 & NS \\
\hline$[5]$ & IHC & 245 & T0-4 & Yes \\
\hline [23] & IHC & 89 & T0-4 & Yes \\
\hline$[28]$ & RT-PCR & 88 & T0-4 & NS \\
\hline [29] & RT-PCR & 73 & T0-4 & NS \\
\hline \multicolumn{5}{|c|}{ ErbB3 or ErbB4 } \\
\hline \multirow[t]{2}{*}{ [16] } & IHC & 128 & T0-4 & NS \\
\hline & $\mathrm{IHC}$ & 124 & T0-4 & Yes \\
\hline
\end{tabular}




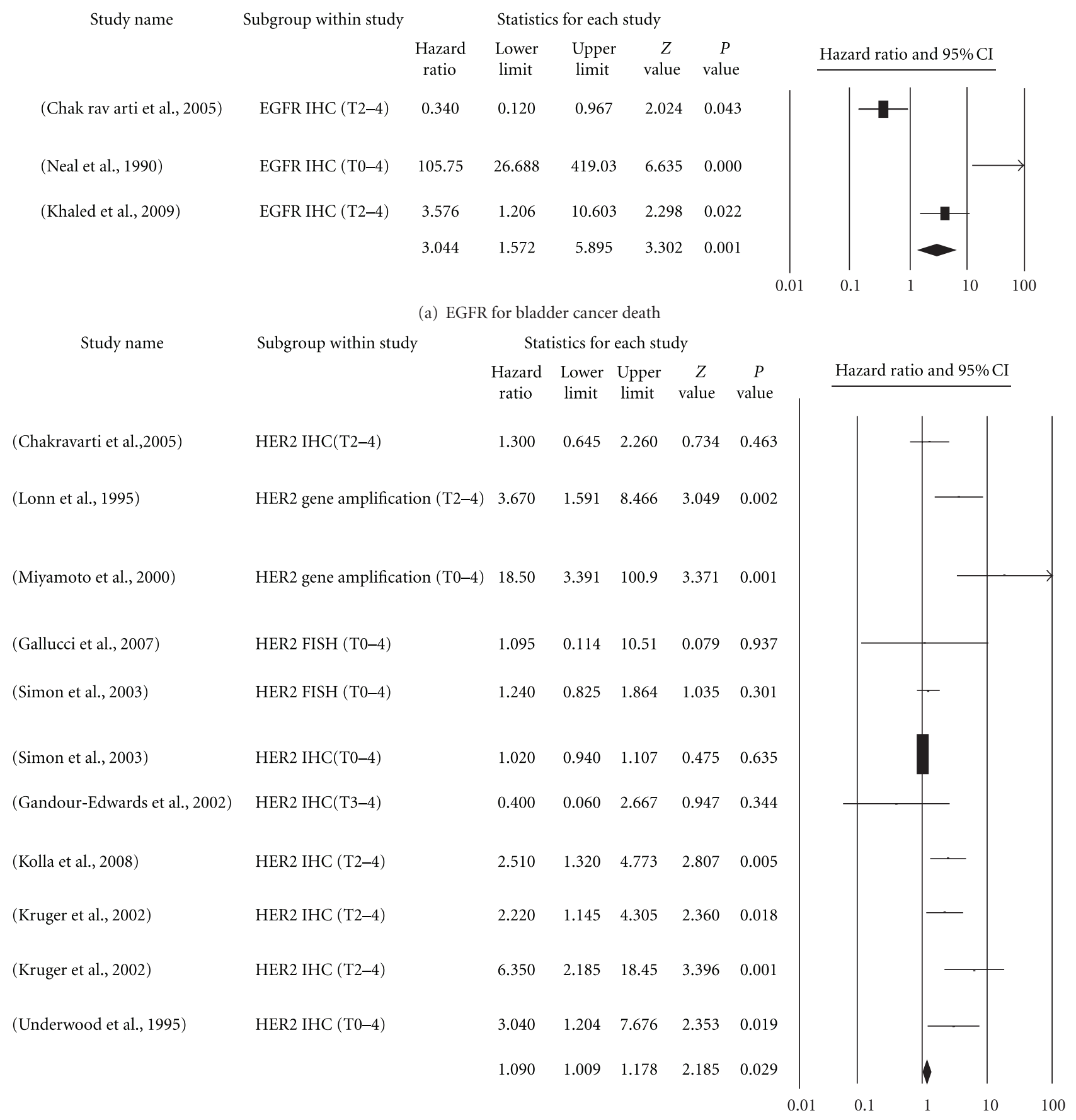

(b) ErbB2 for bladder cancer death

FIGURE 2: Forest plots of prognostic significance of EGFR and ErbB2 overexpression on bladder cancer death. (a) EGFR. (b) ErbB2. Hazard ratios and 95\% (confidence intervals) CIs for patients with either EGFR- or ErbB2-positive tumors.

was stabilized in 18 of these patients (31\%). The result is basically negative. Interestingly, the clinical advantage (ORR and stable disease) correlated with the EGFR overexpression $(P=0.029)$, and, to some extent, HER-2 overexpression.

Vandetanib is a tyrosine kinase inhibitor for EGFR, vascular endothelial growth factor receptor (VEGFR), and (rearranged during transfection) RET. Choueiri et al. reported that combined vandetanib and docetaxel did not provide more benefit for ORR or patient survival than did docetaxel plus placebo in a double-blind trial of 142 patients with metastatic urothelial carcinoma. The toxicity was also greater in the combination group [43]. Taken together, the outcome of current clinical trials suggests that more investigations are required to identify an appropriate strategy or a more effective agent targeting ErbB signaling in the design of treatment for patients with urothelial carcinoma. 
TABLE 4: Co-expression of ErbB receptor family as a marker for bladder cancer prognosis.

\begin{tabular}{lcccll}
\hline Study name & Methods & Pts no. & Study subject & Recurrence & $\begin{array}{c}\text { Significant co-expression pattern for } \\
\text { Survival }\end{array}$ \\
\hline$[5]$ & IHC & 245 & T0-4 & EGFR-ErbB2-ErbB3* & EGFR-ErbB2 \\
{$[16]$} & IHC & 184 & T0-4 & Not significant & High EGFR + low ErbB4 \\
{$[28]$} & RT-PCR & 88 & T0-4 & Not done & High EGFR + low ErbB3 or ErbB4 \\
\hline
\end{tabular}

${ }^{*} P=0.075$.

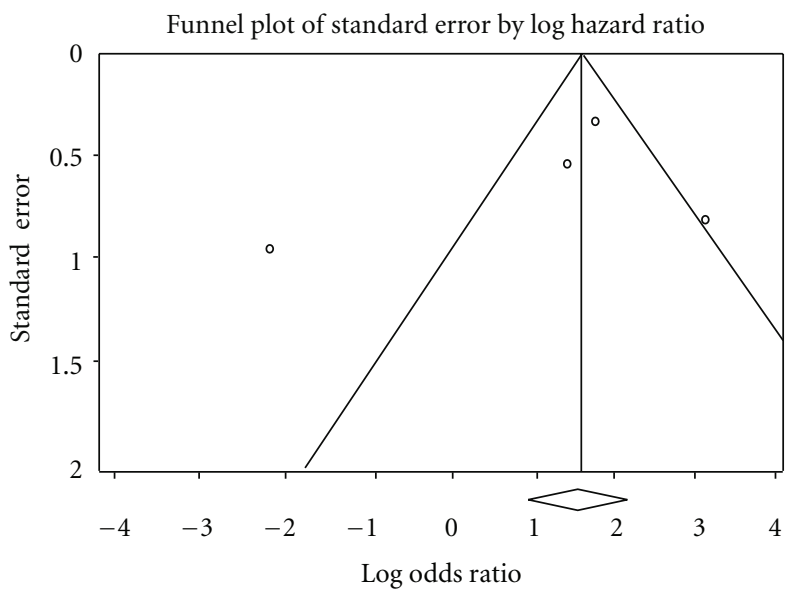

(a) EGFR for bladder cancer progression

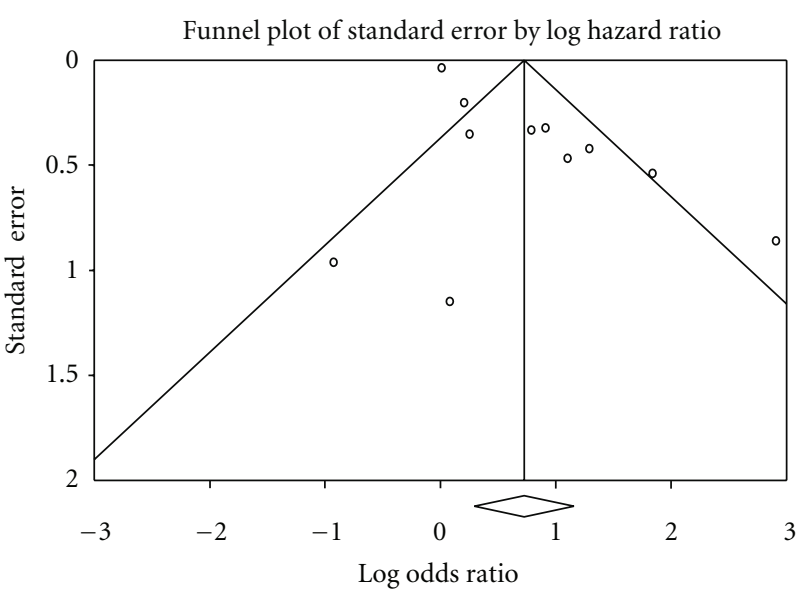

(b) ErbB2 for bladder cancer death

FIGURE 3: Funnel plots of publication bias for EGFR and ErbB2. (a) No obvious funnel plot asymmetry was found for EGFR because only four studies were analyzed. (b) A substantial funnel plot asymmetry for ErbB2 was found, which suggests the existence of publication bias.

\section{Discussion}

This meta-analysis revealed that estimates of the significance of ErbB receptor family member expression vary substantially between studies. Nonetheless, EGFR overexpression is moderately predictive of progression and mortality in patients with bladder cancer. ErbB2 overexpression is weakly predictive of cancer mortality. Since relatively few studies have examined the implications of ErbB3 and ErbB4, no conclusion can be made at this stage. However, these findings should be interpreted carefully because relatively few studies were eligible for analysis.

It has been more than three decades since the discoveries of EGF and EGFR [44, 45]. Many bladder cancer studies examined the signaling events of this receptor family $[16,46$, 47]. Given that human urine contains high concentrations of EGF (20 ng/mg creatinine) [48] and transforming growth factor (TGF) $-\alpha(0.6 \mathrm{ng} / \mathrm{mg}$ creatinine) [49], the interaction of ligands with their cognitive receptors has been thought crucial in the homeostasis of bladder mucosa. This hypothesis is supported by clinical observations that urinary EGF is inversely correlated with the intensity of EGFR expression in primary tumors $(P=0.04)$ [47]. The finding supports the importance of the urinary EGF and urothelial EGFR interaction in the pathogenesis of human bladder cancer.

When ligands bind to the extracellular domains of specific RTKs, tyrosine kinase activity at their intracellular domain is activated [50]. Several regulatory signaling pathways of the ErbB receptor family are important in the proliferation, angiogenesis, migration, and metastasis of human cancer [51]. The conventional paradigm is that aberrant activation of ErbB receptors is generated by the overexpression or mutations of the receptor, and by the autocrine production of ligands [50]. It is now known that signaling output from EGFR is quite complicated. Not only tyrosinephosphorylated EGFR engages at least six biochemical downstream pathways, but EGFR family RTKs include three other receptors, of which only ErbB4 is autonomous [52]. Other ErbB proteins may be coexpressed and activated in the same cell, resulting in their dimerization with EGFR. The association of EGFR with ErbB2 prevents its downregulation, which reinforces the biological effects of EGFR [53].

ErbB signaling may be terminated or blunted by other mechanisms, such as the dissociation of ligands, which causes dephosphorylation or degradation of the receptors $[54,55]$. Alwan et al. hypothesized that proteasomal targeting of ErbB proteins or lysosomal degradation upon ligandinduced endocytosis is involved in EGFR downregulation [56]. Since the ErbB receptor family has many negative feedback mechanisms (e.g., receptor endocytosis, phosphorylation, and ubiquitination/deubiquitination) and crosstalk with other pathways (such as NOTCH pathways, VEGF, and TGF- $\beta$ ), components of the EGFR/ErbB network are excellent targets for cancer therapy [57]. 
TABLE 5: The update results of published clinical trials targeting EGFR signaling in urothelial carcinoma patients.

\begin{tabular}{|c|c|c|c|}
\hline Study agents & Pts no. & ORR (\%) & Recommendation \\
\hline \multicolumn{4}{|l|}{ EGFR signaling } \\
\hline Cetuximab + paclitaxel versus cetuximab & 39 & 28.5 versus 18 & The combination merits further evaluation [38] \\
\hline Geftinib + Gemcitabine, cisplatin & 58 & $42.6 \%$ & $\begin{array}{l}\text { The combination of cisplatin, gemcitabine, and } \\
\text { gefitinib is well tolerated, and the addition of gefitinib } \\
\text { does not appear to improve response rate or survival } \\
{[39,40]}\end{array}$ \\
\hline Geftinib & 31 & 6.5 & $\begin{array}{l}\text { Geftinib (ZD1839) is ineffective as a second-line agent } \\
\text { for urothelial carcinoma [41] }\end{array}$ \\
\hline \multicolumn{4}{|l|}{ EGFR and ErbB2 signaling } \\
\hline Lapatinib & 59 & $\begin{array}{l}\text { ORR }(1.7 \%) \text { and } \\
\operatorname{SD}(31 \%)\end{array}$ & $\begin{array}{l}\text { A negative result, but clinical benefit (ORR and SD) is } \\
\text { correlated with EGFR overexpression }(P=0.029) \text {, and, } \\
\text { to some extent, HER-2 overexpression }[42]\end{array}$ \\
\hline \multicolumn{4}{|l|}{ EGFR, VEGFR, and RET signaling } \\
\hline $\begin{array}{l}\text { Vandetanib plus docetaxel versus placebo } \\
\text { plus docetaxel }\end{array}$ & 142 & $\begin{array}{l}\text { ORR, } 7 \text { versus } 11 \\
(P=0.56) ; P F S \\
2.6 \mathrm{~m} \text { versus } 1.6 \mathrm{~m} \\
(P=0.939) ; \mathrm{OS}, \\
5.9 \mathrm{~m} \text { versus } 7.0 \mathrm{~m} \\
(P=0.347)\end{array}$ & $\begin{array}{l}\text { The addition of vandetanib to docetaxel did not result } \\
\text { in a significant improvement in PFS, ORR, or OS [43] }\end{array}$ \\
\hline
\end{tabular}

ORR: objective response rate; SD: stable disease, PFS: progression-free survival; OS: overall survival; VEGFR: vascular endothelial growth factor receptor; RET: rearranged during transfection.

Several studies have reported that overexpressed or mutant EGFR family members drive the development of human cancers, including lung [58], breast [59], melanoma [60], prostate [61], and urinary bladder cancer [62]. Alternatively, other aberrations, such as mutant forms of RAF or PI3K, manipulate the downstream signaling in cancer through negative feedback loops [63]. Thus, computational charting of EGFR/ErbB signaling may guide the cell-fate decision. Altogether, it is conceivable to speculate that assessing individual ErbB family receptor expression is insufficient for estimating the biological potential of patients with cancer.

A number of studies have reported the association of EGFR and ErbB2 overexpression with advanced stages of bladder cancer. These phenotypes are thought to predict patient survival, as well as the response to chemotherapy $[64,65]$. However, these biomarkers were not included as molecular indicators for patients with bladder cancer [66, 67]. This review describes an authentic inconsistency of the efficacy of ErbB receptor expression in predicting the risk of recurrence, progression, and mortality in patients with bladder cancer. To some extent, this incongruity is consistent with the discouraging results of clinical trials focusing on blockading ErbB receptor signaling [38, 40-43].

Factors responsible for the discrepancies in this metaanalysis include long periods of patient recruitment, a wide range of disease statuses (T0-1, T0-4, T2-4), variability in the immunohistochemical assays used, bias from staining scoring, cutoff points, and subjectivity in interpreting results. There are additional contributing factors, namely, the length of followup, strategies for detecting events of interest, and inconsistency in the inclusion of clinical and pathological factors for multivariate analysis [68]. Not surprisingly, different treatment plans may have different effects on clinical outcome, which might not be considered a confounding factor [69]. The risks calculated in our meta-analysis may be overestimated by reporting biases because hazard ratios and 95\% CIs were not described when associations were not significant.

\section{Conclusions}

In conclusion, this meta-analysis has revealed a significant association between ErbB family receptor expression and progression and mortality in patients with bladder cancer even though these findings need to be carefully interpreted. Considering current molecular information, assessing ErbB family coexpression patterns may provide better prognostic information for patients with bladder cancer. Updated clinical trials suggest that more investigations are required to identify effective agents for targeting ErbB signaling of urothelial carcinoma. Systematic reviews and meta-analyses are mandatory before accepting ErbB receptor expression patterns as predictive markers for clinical application.

\section{Conflict of Interests}

The authors declare no conflict of interests.

\section{Acknowledgments}

This project was supported by Grants NHRI-EX99-9930BI from the National Health Research Institutes and NSC 982314-B-006-033-MY2 from the National Science Council, Taiwan. 


\section{References}

[1] A. Stenzl, N. C. Cowan, M. De Santis et al., "The updated EAU guidelines on muscle-invasive and metastatic bladder cancer," European Urology, vol. 55, no. 4, pp. 815-825, 2009.

[2] M. Rouprêt, R. Zigeuner, J. Palou et al., "European guidelines for the diagnosis and management of upper urinary tract urothelial cell carcinomas: 2011 update," European Urology, vol. 59, no. 4, pp. 584-594, 2011.

[3] C. H. Heldin, "Dimerization of cell surface receptors in signal transduction," Cell, vol. 80, no. 2, pp. 213-223, 1995.

[4] R. Pinkas-Kramarski, M. Shelly, S. Glathe, B. J. Ratzkin, and Y. Yarden, "Neu differentiation factor/neuregulin isoforms activate distinct receptor combinations," Journal of Biological Chemistry, vol. 271, no. 32, pp. 19029-19032, 1996.

[5] N. H. Chow, S. H. Chan, T. S. Tzai, C. L. Ho, and H. S. Liu, "Expression profiles of ErbB family receptors and prognosis in primary transitional cell carcinoma of the urinary bladder," Clinical Cancer Research, vol. 7, no. 7, pp. 1957-1962, 2001.

[6] S. V. Sharma, D. W. Bell, J. Settleman, and D. A. Haber, "Epidermal growth factor receptor mutations in lung cancer," Nature Reviews Cancer, vol. 7, no. 3, pp. 169-181, 2007.

[7] T. J. Lynch, D. W. Bell, R. Sordella et al., "Activating mutations in the epidermal growth factor receptor underlying responsiveness of non-small-cell lung cancer to gefitinib," New England Journal of Medicine, vol. 350, no. 21, pp. 2129-2139, 2004.

[8] K. I. Pritchard, L. E. Shepherd, F. P. O'Malley et al., "HER2 and responsiveness of breast cancer to adjuvant chemotherapy," New England Journal of Medicine, vol. 354, no. 20, pp. 2103 2111, 2006.

[9] D. Slamon, W. Eiermann, N. Robert et al., "Adjuvant trastuzumab in HER2-positive breast cancer," The New England Journal of Medicine, vol. 365, no. 14, pp. 1273-1283, 2011.

[10] M. R. Freeman, "HER2/HER3 heterodimers in prostate cancer: whither HER1/EGFR?” Cancer Cell, vol. 6, no. 5, pp. 427428, 2004

[11] G. Blackledge, W. R. Sellers, and M. R. Smith, "Growth factor receptor tyrosine kinase inhibitors; clinical development and potential for prostate cancer therapy," Journal of Urology, vol. 170, no. 6, pp. S77-S83, 2003.

[12] Y. Yan, G. L. Andriole, P. A. Humphrey, and A. S. Kibel, "Patterns of multiple recurrences of superficial $(\mathrm{Ta} / \mathrm{T} 1)$ transitional cell carcinoma of bladder and effects of clinicopathologic and biochemical factors," Cancer, vol. 95, no. 6, pp. 1239 1246, 2002.

[13] A. Chakravarti, K. Winter, C. L. Wu et al., "Expression of the epidermal growth factor receptor and Her-2 are predictors of favorable outcome and reduced complete response rates, respectively, in patients with muscle-invading bladder cancers treated by concurrent radiation and cisplatin-based chemotherapy: a report from the Radiation Therapy Oncology Group," International Journal of Radiation Oncology Biology Physics, vol. 62, no. 2, pp. 309-317, 2005.

[14] P. Lipponen and M. Eskelinen, "Expression of epidermal growth factor receptor in bladder cancer as related to established prognostic factors, oncoprotein (c-erbB-2, p53) expression and long-term prognosis," British Journal of Cancer, vol. 69, no. 6, pp. 1120-1125, 1994.

[15] D. E. Neal, L. Sharples, K. Smith, J. Fennelly, R. R. Hall, and A. L. Harris, "The epidermal growth factor receptor and the prognosis of bladder cancer," Cancer, vol. 65, no. 7, pp. 1619 $1625,1990$.
[16] W. Kassouf, P. C. Black, T. Tuziak et al., "Distinctive expression pattern of ErbB family receptors signifies an aggressive variant of bladder cancer," Journal of Urology, vol. 179, no. 1, pp. 353358, 2008.

[17] A. Pich, L. Chiusa, A. Formiconi et al., "Proliferative activity is the most significant predictor of recurrence in noninvasive papillary urothelial neoplasms of low malignant potential and grade 1 papillary carcinomas of the bladder," Cancer, vol. 95, no. 4, pp. 784-790, 2002.

[18] B. Têtu, Y. Fradet, P. Allard, C. Veilleux, N. Roberge, and P. Bernard, "Prevalence and clinical significance of HER-2/neu, p53 and Rb expression in primary superficial bladder cancer," Journal of Urology, vol. 155, no. 5, pp. 1784-1788, 1996.

[19] V. Ravery, M. Colombel, Z. Popov et al., "Prognostic value of epidermal growth factor-receptor, T138 and T43 expression in bladder cancer," British Journal of Cancer, vol. 71, no. 1, pp. 196-200, 1995.

[20] Z. Popov, S. Gil-Diez-De-Medina, V. Ravery et al., "Prognostic value of EGF receptor and tumor cell proliferation in bladder cancer: therapeutic implications," Urologic Oncology, vol. 22, no. 2, pp. 93-101, 2004.

[21] M. Gallucci, E. Vico, R. Merola et al., "Adverse genetic prognostic profiles define a poor outcome for cystectomy in bladder cancer," Experimental and Molecular Pathology, vol. 83, no. 3, pp. 385-391, 2007.

[22] R. Gandour-Edwards, P. N. Lara, A. K. Folkins et al., "Does HER2/neu expression provide prognostic information in patients with advanced urothelial carcinoma?" Cancer, vol. 95, no. 5, pp. 1009-1015, 2002.

[23] M. Underwood, J. Bartlett, J. Reeves, D. S. Gardiner, R. Scott, and T. Cooke, "C-erbB-2 gene amplification: a molecular marker in recurrent bladder tumors?” Cancer Research, vol. 55, no. 11, pp. 2422-2430, 1995.

[24] Y. S. Tsai, T. S. Tzai, N. H. Chow et al., "Prognostic values of p53 and HER-2/neu coexpression in invasive bladder cancer in Taiwan," Urologia Internationalis, vol. 71, no. 3, pp. 262-270, 2003.

[25] A. Haitel, B. Posch, M. El-Baz et al., "Bilharzial related, organ confined, muscle invasive bladder cancer: prognostic value of apoptosis markers, proliferation markers, p53, E-cadherin, epidermal growth factor receptor and c-erbB-2," Journal of Urology, vol. 165, no. 5 I, pp. 1481-1487, 2001.

[26] H. M. Khaled, A. A. Bahnassy, A. A. Raafat, A. R. N. Zekri, M. S. Madboul, and N. M. Mokhtar, "Clinical significance of altered nm23-H1, EGFR, RB and p53 expression in bilharzial bladder cancer," BMC Cancer, vol. 9, article 32, 2009.

[27] F. Liedberg, H. Anderson, G. Chebil et al., "Tissue microarray based analysis of prognostic markers in invasive bladder cancer: much effort to no avail?" Urologic Oncology, vol. 26, no. 1, pp. 17-24, 2008.

[28] A. A. Memon, B. S. Sorensen, P. Meldgaard, L. Fokdal, T. Thykjaer, and E. Nexo, "The relation between survival and expression of HER 1 and HER2 depends on the expression of HER3 and HER4: a study in bladder cancer patients," British Journal of Cancer, vol. 94, no. 11, pp. 1703-1709, 2006.

[29] V. B. Thøgersen, B. S. Sørensen, S. S. Poulsen, T. F. Ørntoft, H. Wolf, and E. Nexo, "A subclass of HER1 ligands is a prognostic marker for survival in bladder cancer patients," Cancer Research, vol. 61, no. 16, pp. 6227-6233, 2001.

[30] U. Lonn, S. Lonn, S. Friberg, B. Nilsson, C. Silfversward, and B. Stenkvist, "Prognostic value of amplification of c-erb-B2 in bladder carcinoma," Clinical Cancer Research, vol. 1, no. 10, pp. 1189-1194, 1995. 
[31] H. Miyamoto, Y. Kubota, S. Noguchi et al., "C-erbB-2 gene amplification as a prognostic marker in human bladder cancer," Urology, vol. 55, no. 5, pp. 679-683, 2000.

[32] R. Simon, R. Atefy, U. Wagner et al., "HER-2 and TOP2A coamplification in urinary bladder cancer," International Journal of Cancer, vol. 107, no. 5, pp. 764-772, 2003.

[33] R. E. Jimenez, M. Hussain, F. J. Bianco et al., "Her-2/neu overexpression in muscle-invasive urothelial carcinoma of th bladder: prognostic significance and comparative analysis in primary and metastatic tumors," Clinical Cancer Research, vol. 7, no. 8, pp. 2440-2447, 2001.

[34] S. B. Kolla, A. Seth, M. K. Singh et al., "Prognostic significance of Her2/neu overexpression in patients with muscle invasive urinary bladder cancer treated with radical cystectomy," International Urology and Nephrology, vol. 40, no. 2, pp. 321$327,2008$.

[35] S. Krüger, G. Weitsch, H. Büttner et al., "HER2 overexpression in muscle-invasive urothelial carcinoma of the bladder: prognostic implications," International Journal of Cancer, vol. 102, no. 5, pp. 514-518, 2002.

[36] S. Krüger, A. Mahnken, I. Kausch, and A. C. Feller, "Value of clusterin immunoreactivity as a predictive factor in muscleinvasive urothelial bladder carcinoma," Urology, vol. 67, no. 1, pp. 105-109, 2006.

[37] K. Sato, M. Moriyama, S. Mori et al., "An immunohistologic evaluation of c-erbB-2 gene product in patients with urinary bladder carcinoma," Cancer, vol. 70, no. 10, pp. 2493-2498, 1992.

[38] Y. L. S. Wong, E. R. Plimack, D. J. Vaughn et al., "Effect of EGFR inhibition with cetuximab on the efficacy of paclitaxel in previously treated metastatic urothelial cancer," Journal of Clinical Oncology, vol. 29, supplement 7, abstract 243, 2011.

[39] G. K. Philips, S. Halabi, B. L. Sanford, D. Bajorin, and E. J. Small, "A phase II trial of cisplatin, fixed dose-rate gemcitabine and gefitinib for advanced urothelial tract carcinoma: results of the Cancer and Leukaemia Group B 90102," British Journal of Urology International, vol. 101, no. 1, pp. 20-25, 2008.

[40] G. K. Philips, S. Halabi, B. L. Sanford, D. Bajorin, and E. J. Small, "A phase II trial of cisplatin (C), gemcitabine (G) and gefitinib for advanced urothelial tract carcinoma: results of Cancer and Leukemia Group B (CALGB) 90102," Annals of Oncology, vol. 20, no. 6, pp. 1074-1079, 2009.

[41] D. P. Petrylak, C. M. Tangen, P. J. Van Veldhuizen et al., "Results: of the Southwest Oncology Group phase II evaluation (study S0031) of ZD1839 for advanced transitional cell carcinoma of the urothelium," British Journal of Urology International, vol. 105, no. 3, pp. 317-321, 2010.

[42] C. Wülfing, J. P. H. Machiels, D. J. Richel et al., "A singlearm, multicenter, open-label phase 2 study of lapatinib as the second-line treatment of patients with locally advanced or metastatic transitional cell carcinoma," Cancer, vol. 115, no. 13, pp. 2881-2890, 2009.

[43] T. K. Choueiri, R. W. Ross, S. Jacobus et al., "Double-blind, randomized trial of docetaxel plus vandetanib versus docetaxel plus placebo in platinum-pretreated metastatic urothelial cancer," Journal of Clinical Oncology, vol. 30, no. 5, pp. 507-512, 2012.

[44] M. Heimberg, I. Weinstein, V. S. LeQuire, and S. Cohen, “The induction of fatty liver in neonatal animals by a purified protein (EGF) from mouse submaxillary gland," Life Sciences, vol. 4, no. 17, pp. 1625-1633, 1965.

[45] S. Cohen, G. Carpenter, and L. King, "Epidermal growth factor-receptor-protein kinase interactions. Co-purification of receptor and epidermal growth factor-enhanced phosphorylation activity," Journal of Biological Chemistry, vol. 255, no. 10, pp. 4834-4842, 1980.

[46] D. E. Neal, K. Smith, J. A. Fennelly, M. K. Bennett, R. R. Hall, and A. L. Harris, "Epidermal growth factor receptor in human bladder cancer: a comparison of immunohistochemistry and ligand binding," Journal of Urology, vol. 141, no. 3 I, pp. 517$521,1989$.

[47] N. H. Chow, H. S. Liu, E. I. C. Lee et al., "Significance of urinary epidermal growth factor and its receptor expression in human bladder cancer," Anticancer Research, vol. 17, no. 2B, pp. 1293-1296, 1997.

[48] A. L. Mattila, J. Perheentupa, K. Pesonen, and L. Viinikka, "Epidermal growth factor in human urine from birth to puberty," Journal of Clinical Endocrinology and Metabolism, vol. 61, no. 5, pp. 997-1000, 1985.

[49] K. Stromberg, M. Duffy, C. Fritsch et al., "Comparison of urinary transforming growth factor-alpha in women with disseminated breast cancer and healthy control women," Cancer Detection and Prevention, vol. 15, no. 4, pp. 277-283, 1991.

[50] A. Ullrich and J. Schlessinger, "Signal transduction by receptors with tyrosine kinase activity," Cell, vol. 61, no. 2, pp. 203212, 1990.

[51] M. A. Lemmon and J. Schlessinger, "Cell signaling by receptor tyrosine kinases," Cell, vol. 141, no. 7, pp. 1117-1134, 2010.

[52] M. A. Olayioye, R. M. Neve, H. A. Lane, and N. E. Hynes, "The ErbB signaling network: receptor heterodimerization in development and cancer," EMBO Journal, vol. 19, no. 13, pp. 3159-3167, 2000.

[53] M. A. Olayioye, D. Graus-Porta, R. R. Beerli, J. Rohrer, B. Gay, and N. E. Hynes, "ErbB-1 and ErbB-2 acquire distinct signaling properties dependent upon their dimerization partner," Molecular and Cellular Biology, vol. 18, no. 9, pp. 5042-5051, 1998.

[54] J. Yoshida, T. Ishibashi, and M. Nishio, "Growth-inhibitory effect of a streptococcal antitumor glycoprotein on human epidermoid carcinoma A431 cells: involvement of dephosphorylation of epidermal growth factor receptor," Cancer Research, vol. 61, no. 16, pp. 6151-6157, 2001.

[55] X. B. Qiu and A. L. Goldberg, "Nrdp1/FLRF is a ubiquitin ligase promoting ubiquitination and degradation of the epidermal growth factor receptor family member, ErbB3," Proceedings of the National Academy of Sciences of the United States of America, vol. 99, no. 23, pp. 14843-14848, 2002.

[56] H. A. J. Alwan, E. J. J. Van Zoelen, and J. E. M. Van Leeuwen, "Ligand-induced lysosomal epidermal growth factor receptor (EGFR) degradation is preceded by proteasome-dependent EGFR de-ubiquitination," Journal of Biological Chemistry, vol. 278, no. 37, pp. 35781-35790, 2003.

[57] P. O. Hackel, E. Zwick, N. Prenzel, and A. Ullrich, "Epidermal growth factor receptors: critical mediators of multiple receptor pathways," Current Opinion in Cell Biology, vol. 11, no. 2, pp. 184-189, 1999.

[58] J. L. Marks, M. McLellan, M. F. Zakowski et al., "Mutational analysis of EGFR and related signaling pathway genes in lung adenocarcinomas identifies a novel somatic kinase domain mutation in FGFR4," PLoS ONE, vol. 2, no. 5, article e426, 2007.

[59] Y. Nieto, F. Nawaz, R. B. Jones, E. J. Shpall, and S. Nawaz, "Prognostic significance of overexpression and phosphorylation of Epidermal Growth Factor Receptor (EGFR) and the presence of truncated EGFRvIII in locoregionally advanced breast cancer," Journal of Clinical Oncology, vol. 25, no. 28, pp. 4405-4413, 2007. 
[60] L. A. Akslen, H. Puntervoll, I. M. Bachmann et al., "Mutation analysis of the EGFR-NRAS-BRAF pathway in melanomas from black Africans and other subgroups of cutaneous melanoma," Melanoma Research, vol. 18, no. 1, pp. 29-35, 2008.

[61] C. Peraldo-Neia, G. Migliardi, M. Mello-Grand et al., "Epidermal Growth Factor Receptor (EGFR) mutation analysis, gene expression profiling and EGFR protein expression in primary prostate cancer," BMC Cancer, vol. 11, article 31, 2011.

[62] Z. Latif, A. D. Watters, I. Dunn, K. M. Grigor, M. Underwood, and J. Bartlett, "HER2/neu overexpression in the development of muscle-invasive transitional cell carcinoma of the bladder," British Journal of Cancer, vol. 89, no. 7, pp. 1305-1309, 2003.

[63] R. Avraham and Y. Yarden, "Feedback regulation of EGFR signalling: decision making by early and delayed loops," Nature Reviews Molecular Cell Biology, vol. 12, no. 2, pp. 104117, 2011.

[64] D. Amsellem-Ouazana, P. Beuzeboc, M. Peyromaure, A. Viellefond, M. Zerbib, and B. Debre, "Management of primary resistance to gemcitabine and cisplatin (G-C) chemotherapy in metastatic bladder cancer with HER2 over-expression," Annals of Oncology, vol. 15, no. 3, p. 538, 2004.

[65] Y. S. Tsai, T. S. Tzai, and N. H. Chow, "Does HER2 immunoreactivity provide prognostic information in locally advanced urothelial carcinoma patients receiving adjuvant M-VEC chemotherapy?" Urologia Internationalis, vol. 79, no. 3, pp. 210-216, 2007.

[66] P. Puppo, G. Conti, F. Francesca, A. Mandressi, and A. Naselli, "New Italian guidelines on bladder cancer, based on the World Health Organization 2004 classification," British Journal of Urology International, vol. 106, no. 2, pp. 168-179, 2010.

[67] A. Stenzl, N. C. Cowan, M. De Santis et al., "Treatment of muscle-invasive and metastatic bladder cancer: update of the EAU guidelines," European Urology, vol. 59, no. 6, pp. 1009-1018, 2011.

[68] A. Laupacis, G. Wells, W. S. Richardson et al., "Users' guides to the medical literature: V. How to use an article about prognosis," Journal of the American Medical Association, vol. 272, no. 3, pp. 234-237, 1994.

[69] N. Malats, A. Bustos, C. M. Nascimento et al., "P53 as a prognostic marker for bladder cancer: a meta-analysis and review," Lancet Oncology, vol. 6, no. 9, pp. 678-686, 2005. 


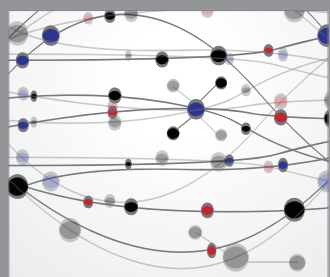

The Scientific World Journal
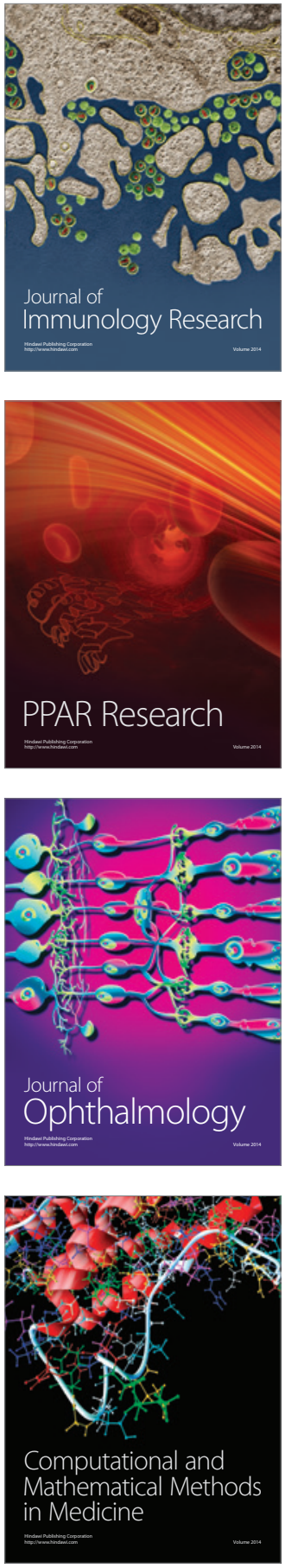

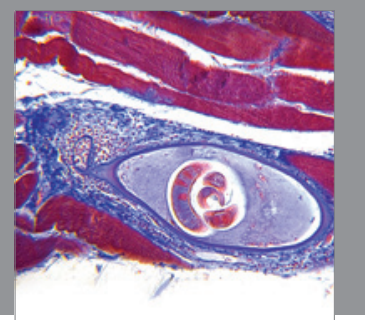

Gastroenterology

Research and Practice
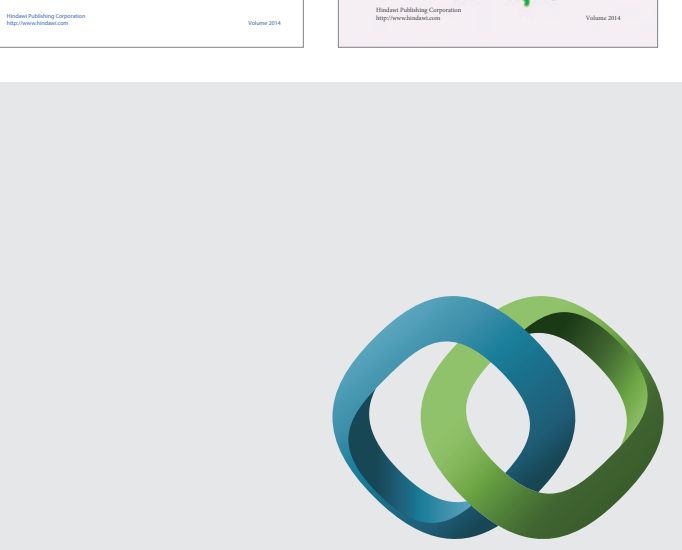

\section{Hindawi}

Submit your manuscripts at

http://www.hindawi.com
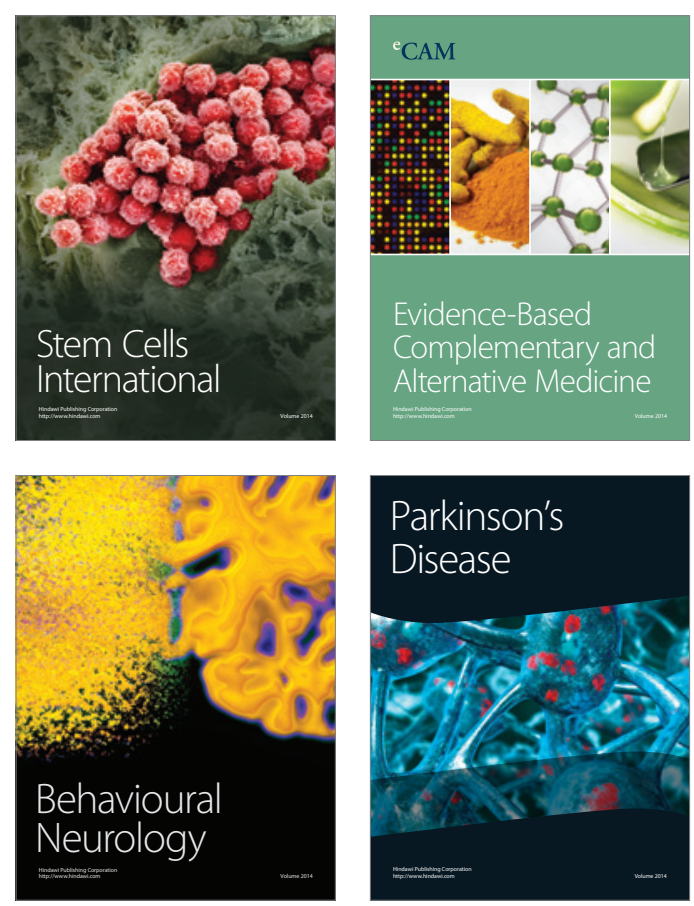

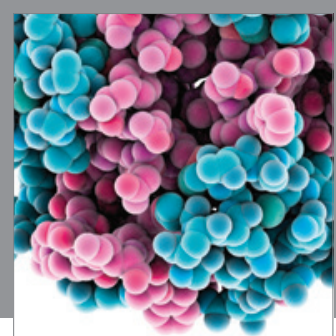

Journal of
Diabetes Research

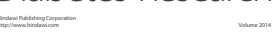

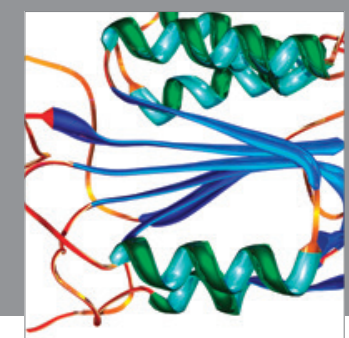

Disease Markers
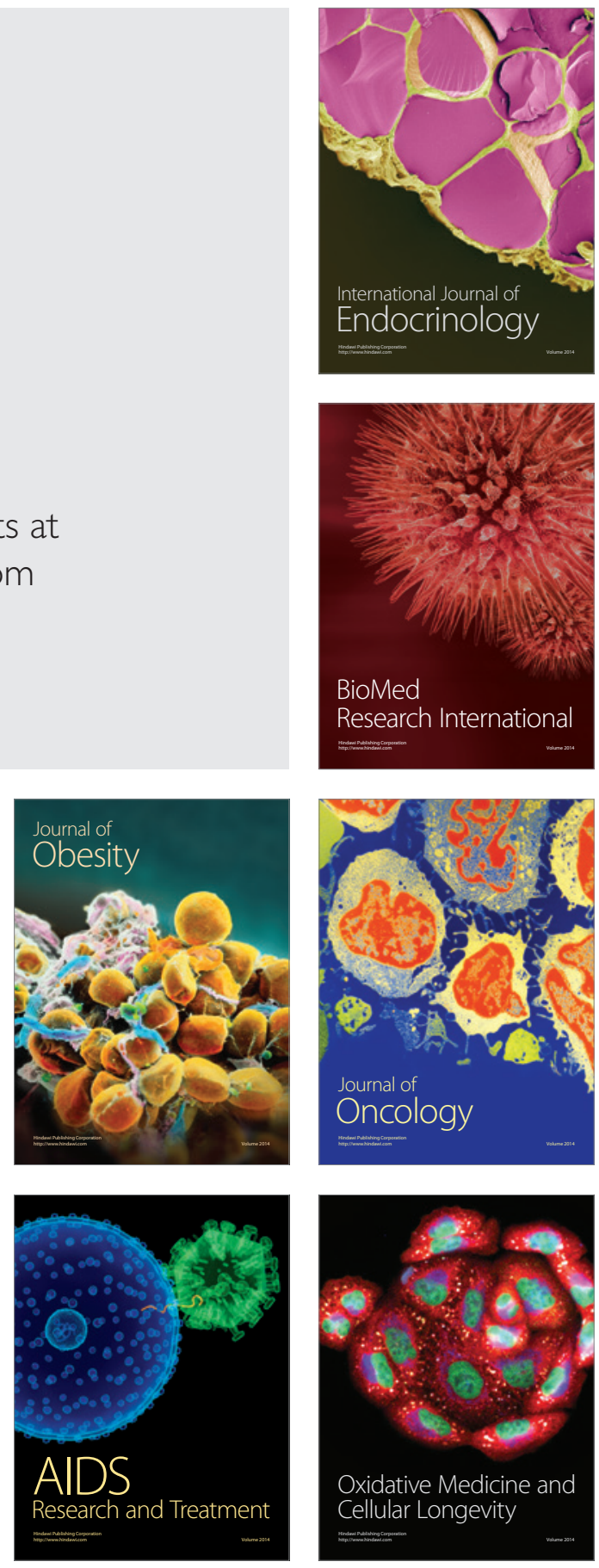